\title{
50 years since the discovery of bromocriptine
}

\author{
G Michael Besser ${ }^{1}$, Ronald F Pfeiffer ${ }^{2}$ and Michael 0 Thorner ${ }^{3}$
}

${ }^{1}$ Medicine, St Bartholomew's Hospital, London, UK, ${ }^{2}$ Neurology, Oregon Health \& Science University, Portland, Oregon, USA, and ${ }^{3}$ Medicine, University of Virginia, Charlottesville, Virginia, USA

Correspondence should be addressed to M O Thorner

Email

mot@virginia.edu

\begin{abstract}
Ergotism is the long-term ergot poisoning by ingestion of rye or other grains infected with the fungus Claviceps purpurea and more recently by excessive intake of ergot drugs. It has either neuropsychiatric or vascular manifestations. In the Middle Ages, the gangrenous poisoning was known as St. Anthony's fire, after the order of the Monks of St. Anthony who were particularly skilled at treating the condition. In 1917, Prof. Arthur Stoll returned home to Switzerland from Germany, to lead the development of a new pharmaceutical department at Sandoz Chemical Company. Stoll, using the special methods of extraction learned from his work with his mentor Willstetter, started his industrial research work with ergot. He succeeded in isolating, from the ergot of rye, ergotamine as an active principle of an old popular remedy for excessive post-partum bleeding. The success of this discovery occurred in 1918 and was translated into a pharmaceutical product in 1921 under the trade name Gynergen. In subsequent work, Stoll and his team were leaders in identifying the structure of the many other alkaloids and amines produced by Claviceps purpurea. This was the cultural background and scientific foundation on which bromocriptine was discovered.
\end{abstract}

\section{Introduction}

It is 50 years since the discovery of 2 - $\mathrm{Br}$ - $\alpha$-bromoergokryptine mesylate, (CB154) bromocriptine (1). Today, no one questions the importance of dopamine agonist drugs in therapy of endocrine and neurological diseases. Not so in the early 1970s. It was at this exciting time in neuroendocrinology that the hypothalamic hormones were being identified, isolated and sequenced and then studied in man. It is worth recounting the story of bromocriptine's discovery as it is quite remarkable and reflects the wisdom and perseverance of its founder, Prof. Edward Flückiger.

\section{Invited Author's profile}

Michael 0 Thorner, Emeritus Professor of Medicine, University of Virginia, has studied hypothalamic pituitary physiology and pathophysiology. His contributions include the demonstration that prolactin-secreting pituitary tumors can be treated with dopamine agonist drugs, and identification of pancreatic tumor in a patient with acromegaly. His research interest has been the decline of growth hormone secretion during aging and its reversibility with growth hormone secretagogues. He has been made Fellow, American Academy of Arts and Sciences, Master, American College of Physicians (ACP), and received ACP John Phillips Memorial Award, Endocrine Society Edwin B. Astwood, Distinguished Physician and Fred Conrad Koch Awards, and the Dale Medal of the Society for Endocrinology.

(C) 2018 European Society of Endocrinology Printed in Great Britain
Published by Bioscientifica Ltd.

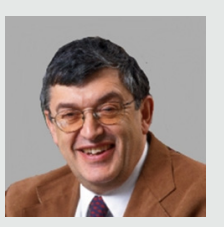


Prof. Flückiger was working at Sandoz Pharmaceuticals, which is now Novartis. He set out to build on the work of Shelesnyak who was an American scientist working at the Weitzman Institute in Israel. In 1954, Shelesnyak published the first paper showing that the ergot extract known as ergotoxine, a mixture of ergocornine, ergocryptine and ergocristine, inhibited the formation of deciduomata in pseudopregnant rats and also interfered with early gestation in the rat by preventing progresterone production by the corpus luteum it prevented implantation of the fertilized ovum and thus had an anti-fertility effect $(2,3)$. He demonstrated that these effects were mediated by ergocornine and used it as an investigative pharmacological probe to help understand the mechanisms underlying the implantation of the fertilized ovum in the endometrium (4). He was studying rat physiology and through a series of logical and remarkable studies, he identified that ergocornine suppressed prolactin and that prolactin was responsible for sustaining the production of progesterone for the implantation of the fertilized ovum $(4,5)$.

Flückiger realized that ergocornine could not be used in humans due to its oxytocic and vascular effects (6). He therefore set out to modify its structure and bring out the prolactin-lowering action without the oxytocic or vascular effects. Bromocriptine was the compound which he made and which became the first dopamine agonist to be approved for treatment of patients.

The story is even more remarkable when considering that at that time $\mathrm{C} \mathrm{H} \mathrm{Li}$, who had been responsible previously for isolating so many purified pituitary hormones, had stated that prolactin did not exist in the human and all lactogenic action in human blood could be explained by growth hormone (GH). Both $\mathrm{GH}$ and prolactin are equally effective in stimulating prolactin receptors. However, the denial of the existence as a separate hormone could not explain the many acromegalic patients who did not have galactorrhea or others with galactorrhea and hypogonadism who did not have acromegaly.

No immunoassays were available at that time for measurement of either GH or prolactin. Thus, Prof. Flückiger had to rely on in vivo bioassays when studying the prolactin activities in his rats - suppression of lactation, inhibition of implantation of the fertilized ovum or blocking pseudopregnancy. We now know that prolactin has different roles in humans than in the rat. It is not luteotrophic and suppression of prolactin restores fertility in patients with hyperprolactinemia. The next twist in the story was that bromocriptine was developed as an inhibitor of prolactin secretion in the human. Dopamine receptors had not yet been identified and it was unknown how ergocryptine or bromocriptine suppressed prolactin secretion.

Each one of these statements could be the subject of a whole article so here we would just like to point to some of the key observations and the investigators who made them. Andrew Frantz and Michael Besser and their respective colleagues at Columbia University, New York and St. Bartholomew's Hospital in London finally demonstrated that prolactin and GH existed separately in the human. They developed new more sensitive bioassays. Instead of using the very insensitive pigeon crop assay, they used breast tissue in organ culture (from mice and rabbits respectively) and were able to show that prolactin-like lactogenic bioactivity existed in the circulation of patients with galactorrhea in whom GH levels were very low, and that further that this lactogenic activity could not be blocked by specific anti-GH antisera $(7,8,9)$. The group at St. Bartholomew's Hospital were the first investigators then allowed to perform clinical studies with bromocriptine; they did so in male and female patients with inappropriate lactation and hypogonadism who had been shown to have hyperprolactinemia. They demonstrated that bromocriptine (then known as CB154 or bromoergocriptine) rapidly lowered the elevated circulating prolactin levels and resulted in immediate reversal of the patients' hypogonadism. Menstruation and potency returned even if the hypogonadism had been present for many years. The effect was dramatic (10). Similar studies confirming these effects were performed by Emilio del Pozo in Switzerland $(11,12)$.

As these clinical studies were underway, Robert MacLeod at the University of Virginia was studying the control of prolactin release from hemipituitaries in shortterm culture. He was measuring prolactin at that time from a band on gel electrophoresis and showed that prolactin synthesis/secretion was suppressed by epinephrine, norepinephrine and dopamine (13). However, the antisecretory effect was not blocked by alpha or beta blockade but was blocked by phenothiazines and haloperidol. Similarly, the inhibitory effect of ergocryptine could be blocked by these neuroleptic drugs, suggesting that there were new receptors involved. These were later shown to be D2 dopamine receptors. MacLeod was fighting an uphill battle in suggesting that the hypothalamic prolactininhibiting factor might be related to a catecholaminelike substance as the conventional wisdom at that time was that all hypothalamic regulatory hormones would be 
peptides. Thus, to suggest that the prolactin-inhibiting hormone was dopamine was controversial (13).

Henry Friesen and his colleagues in Winnipeg in Canada ultimately isolated prolactin (14). Corrodi and Fuxe in Stockholm demonstrated that dopamine turnover was increased when prolactin was injected into the hypothalamus and that treatment of a rat with bromocriptine reduced dopamine turnover (15). All this supported MacLeod's hypothesis. Later, dopamine was isolated from portal blood and it became generally accepted that dopamine is the prolactininhibiting hormone which tonically suppresses prolactin secretion (16).

The efficacy of bromocriptine in treating hyperprolactinemia was rapidly acknowledged. The diagnosis of hyperprolactinemia increased dramatically as physicians became aware of its existence and it became the most common hypothalamic/pituitary disorder. We know that pituitary tumors are common and approximately $50 \%$ of them are prolactinomas. In women with menstrual dysfunction who harbored small tumors and hyperprolactinemia reliably could be treated with bromocriptine with restoration of normal gonadal function $(10,12,17)$. Their prior dysfunction included menstrual dysfunction ranging from amenorrhea to oligomenorrhea and luteal dysfunction. Measurement of a serum prolactin could easily diagnose hyperprolactinemia. Men with hyperprolactinemia have lack of libido and impotence which are reversed with bromocriptine therapy. Initially, it was unclear whether bromocriptine had an effect on the pituitary tumor size and therefore many patients had pituitary radiation therapy or transsphenoidal or transfrontal surgery. These therapies rarely normalized the prolactin. Michael Thorner was fortunate when he arrived at the University of Virginia to be referred a young man with a very large pituitary tumor, severe visual field defects, severe headaches and hypogonadism. The standard of care at that time in such patients with large pituitary tumors was neurosurgical - attempted removal. This patient refused and he was offered experimental medical treatment as an inpatient. Following receiving appropriate approval from the Human Investigation Committee, the patient was admitted and following the first dose of bromocriptine, his catastrophic headache improved and by day 3 , his visual fields also began to improve (Fig. 1) and by 2 weeks, his pituitary tumor was shown to have reduced in size (18). Later, in collaboration with Kalman Kovacs in Toronto and George Tindall in Atlanta, pituitary tumors were collected from patients with pituitary macroadenomas who had been
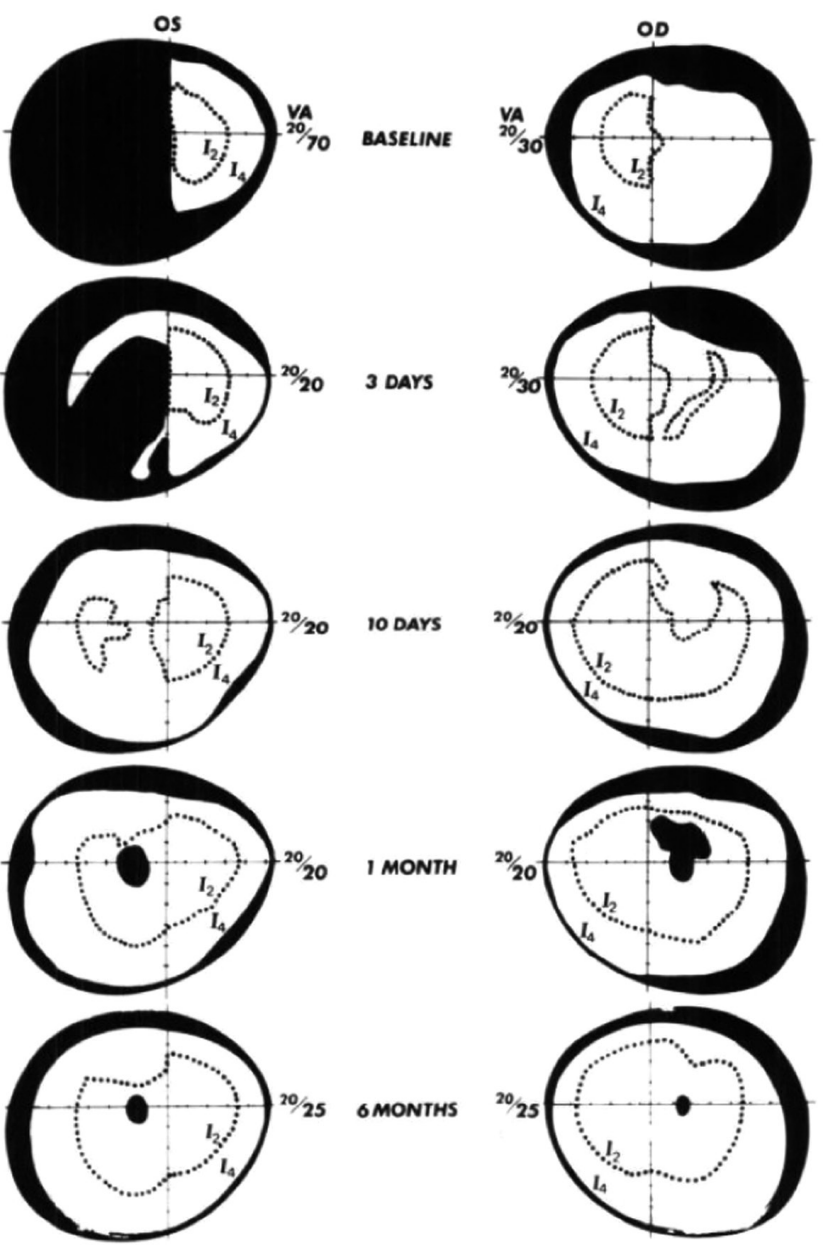

Figure 1

Visual acuity and diagrammatic representation of visual field plots before and during 6 months of bromocriptine therapy. The visual fields were plotted by one observer using the Goldman apparatus under identical conditions with a $0.25 \mathrm{~mm}^{2}$ object at two different light intensities, 1000 apostilb (Li) and 100 apostilb (I2). The black periphery indicates a normal visual field for comparison. Before therapy, a complete temporal hemianopsia in the left eye and an incomplete hemianopsia in the right eye were present, with reduced visual acuity in both. After 3 days, the left visual field had improved, and visual acuity was restored to 20/20.

Thereafter, progressive improvement in the visual fields was noted; the only abnormality at 6 months was an equivocal superior bitemporal quadrantic defect to the low-intensity object. Reproduced with permission from Thorner et al. (18).

treated for 6 weeks prior to surgery. The prolactin tumor cells demonstrated that the volume of the tumor cells were reduced 20 fold, but this did not occur in the 'non'functioning tumors (19). Further, if treatment was stopped 
after a year of treatment, the tumor could re-expand and thus long-term therapy was required (20). The role of bromocriptine and the later developed dopamine agonists is established in patients with prolactinomas and is reviewed by Molitch (21). Today, cabergoline is the preferred drug due to its long duration of action such that it can be administered once or twice per week.

In his studies on GH secretion, Liuzzi and his colleagues in Italy had identified that L-Dopa stimulated GH secretion in normal subjects. However, there was a surprising and paradoxical suppression in patients with acromegaly (22). Several groups including those at St. Bartholomew's Hospital in London and the Italian group performed studies in patients with acromegaly. It was not as effective as in prolactinomas, but it did lower GH and IGF-I levels in most but not all patients and most importantly relieved many of the symptoms including hyperhidrosis, joint pain and swelling of the digits so that ring size was reduced $(23,24,25,26)$. As the more active somatostatin analogs were introduced followed by the GH receptor antagonist pegvisomant, DA agonists became less used. However, it is an oral therapy and although higher doses are required than are needed in hyperprolactinemia, it can be effective particularly in patients with mild elevation of GH levels. As in prolactinomas, cabergoline is the drug of choice today for treatment by a dopamine agonist in acromegaly. This was reviewed by Giustina and colleagues (27).

Parkinson's disease (28) and neurological indications: The introduction of levodopa in the 1960s had revolutionized the treatment of Parkinson's disease (PD) (29). The initial response to levodopa often was dramatic and raised hopes that levodopa might even be a cure for the disorder. With the passage of time, however, it became clear that such was not the case. The response to levodopa frequently became marred by fluctuations in motor response, in which the duration of efficacy of a dose of levodopa became progressively shorter. Dyskinetic movements, typically choreiform in character, also appeared in many individuals treated with levodopa and it became obvious that more effective treatment was still sorely needed.

The knowledge that bromocriptine was a dopamine agonist led Donald Calne and his colleagues, initially at Hammersmith Hospital in London and later at the National Institutes of Health in Bethesda, to evaluate bromocriptine in patients with PD. Clinical trials with two earlier dopamine agonists, apomorphine (30) and piribedil (31), had been disappointing due to adverse effects, but Calne and colleagues found that bromocriptine at doses up to $30 \mathrm{mg}$ daily, when added to levodopa, was tolerated and provided improvement in motor function (32). Subsequent studies reported that bromocriptine in doses up to $100 \mathrm{mg}$ daily provided improvement both as monotherapy and when used in conjunction with levodopa and that at higher doses, a therapeutic effect comparable to levodopa could be achieved $(28,3334,35)$. The fact that bromocriptine, unlike levodopa which must be converted to dopamine by dopa decarboxylase, directly stimulates dopamine receptors was also considered to open the possibility that bromocriptine might be effective even in patients who were no longer responding adequately to levodopa. The success of bromocriptine soon led to the development of an expanding array of still newer dopamine agonists.

As the potential role for bromocriptine and other dopamine agonists in the treatment of PD was unfolding, another landmark advance in the understanding of dopaminergic function was emerging, culminating in the proposal in 1979 by John Kebabian and Donald Calne that there are two distinct categories of dopamine receptor, which they designated D1 and D2 (36). Subsequent research utilizing molecular biological techniques expanded the number of dopamine receptors to five, but the five could still be placed within the two dopamine receptor families described earlier (37). This further fueled the search for additional dopamine agonists, with the hope that dopamine agonists selective for striatal dopamine receptors could be discovered that would be even more effective and less likely to produce adverse effects.

The 1980s and 1990s were an era of proliferation of dopamine agonists, with the introduction of lergotrile, lisuride, pergolide, mesulergine, cabergoline and others. Like bromocriptine, all were selective for the $\mathrm{D} 2$ receptor family, with some variability in subtype selectivity. It is unfortunate and perhaps surprising that no selective D1 receptor agonist ever passed the pharmacological gauntlet to human use. The promise of precisely selective dopamine receptor agonists was not achieved. During these years, controversy swirled around the question of whether PD treatment should begin with levodopa or with a dopamine agonist such as bromocriptine. Those favoring levodopa pointed to its superior efficacy and lower likelihood of producing psychiatric toxicity; those favoring dopamine agonists focused on the reduced risk of developing motor fluctuations with dopamine agonists and suggested that levodopa itself may be toxic to dopamine neurons by means of free radical production. The concept of using bromocriptine and other dopamine agonists as a levodopa-sparing treatment strategy was 
popularized and it was not until a number of years later that the idea of levodopa toxicity was disproven (38) and what was labeled by some as "levodopa phobia" (39) was placed to rest.

It is not correct to say, however, that there were no differences between the various dopamine agonists and it was one important difference that led to the demise of bromocriptine as the primary dopamine agonist used in the treatment of PD. Several of the dopamine agonists (bromocriptine, pergolide, cabergoline) were ergot derivatives, and with the increasing use of highdose bromocriptine therapy in the treatment of PD in the 1980s, some adverse effects began to appear that could be traced to the ergot properties of the drugs. The appearance of pleuropulmonary changes in PD patients following prolonged administration of bromocriptine was first reported by Rinne in 1981 (40). Over the next several years, a growing number of reported cases surfaced and in 1988, McElvaney and colleagues suggested that the prevalence of pleuropulmonary changes in individuals with $\mathrm{PD}$ treated with bromocriptine was in the range of $2-5 \%$ (41). Constrictive pericarditis, valvular heart disease and retroperitoneal fibrosis also were reported predominantly at doses at or above $20 \mathrm{mg} /$ day when dosed multiple times during the day. The recognition that these complications of therapy, although often reversible following discontinuation of the offending drug, could be avoided by using one of the non-ergot dopamine agonists such as ropinirole or pramipexole, which had been approved for use in the USA in 1997, led to a gradual abandonment of bromocriptine as the primary dopamine agonist therapy for PD. The recognition of other treatment complications, such as excessive sleepiness and impulse control disorders, in more recent years has further tempered the enthusiasm for the use of dopamine agonists, although they still retain an important place in the treatment armamentarium, both for PD and for restless legs syndrome. Although bromocriptine has largely passed from the PD treatment stage, it has left a lasting legacy as the pioneer dopamine agonist first successfully employed in the treatment of PD.

Bromocriptine is approved in the USA for the treatment of hyperprolactinemia-associated dysfunctions including pituitary tumors, acromegaly and PD. It has been used for multiple other indications and after the first 10 years, Prof. Flückiger, Donald Calne and Thorner wrote a monograph which discussed the state of art at that time and where it was being researched (42). In 2009, bromocriptine was approved for the treatment of diabetes mellitus type 2 (T2DM) at dosages generally much less than used for the treatment of PD or hyperprolactinemia or acromegaly. This is for a new formulation (Cycloset) which is dosed only once daily in the morning within $2 \mathrm{~h}$ of waking and designed to be more rapidly absorbed and have a shorter duration of action (Table 1). Its role is described by deFronzo (43). It appears to have great promise but has not been widely adopted as yet. At doses of $1.6-4.8 \mathrm{mg} /$ day, it lowers HbA1c in T2DM subjects by $0.5-0.9$ as add-on therapy to oral anti-diabetes agents and by 1.1-1.8 as add-on therapy to metformin plus basal/bolus insulin (44). This Cycloset effect appears to be mainly (though not solely) via action on postprandial hyperglycemia. Circadian-timed Cycloset also reduces fasting and postmeal plasma free fatty acid and triglyceride levels. It was shown in a randomized, double-blind, 1-year safety study of some $\sim 3000$ patients to lower the composite cardiovascular endpoint of myocardial infarction, stroke, hospitalization for congestive heart failure, unstable angina and revascularization surgery by $39 \%$ (45). This may be due to its lowering of sympathetic drive due to an action at the ventromedial nucleus of the hypothalamus and through connections to the suprachiasmatic nucleus that affect sympathetic outflow to the periphery (44). Studies performed in experimental model of the SHR rat demonstrate that injection of bromocriptine once daily 1 hour before lights off leads to remarkable changes including: reduced ventromedial hypothalamic

Table 1 Comparison of key bioavailability characteristics of Cycloset and Parlodel.

\begin{tabular}{|c|c|c|}
\hline & Cycloset & Parlodel \\
\hline Bromocriptine form & $\begin{array}{l}\text { Micronized to specific particle size distribution to } \\
\text { generate specific dissolution profile }\end{array}$ & Non-micronized \\
\hline Bioavailability (absorbed dose) & $65-95 \%$ & $28 \%$ \\
\hline Unabsorbed dose & $5-25 \%$ & $72 \%$ \\
\hline Time to maximum plasma level & $53 \mathrm{~min}$ & $1-3 h$ \\
\hline Elimination half life & $6 \mathrm{~h}$ & $15 \mathrm{~h}$ \\
\hline Approved indication & Glycemic control & $\begin{array}{l}\text { Parkinson's disease and endocrine-related } \\
\text { diseases }\end{array}$ \\
\hline
\end{tabular}

Parlodel (package insert). Suffern, NY, and East Hanover, NJ; Novartis Pharmaceuticals Corporation, 2006; Cycloset Package Insert 2016; and VeroScience LLC, Tiverton, RI. Reproduced with Permission from Anthony Cincotta, VeroScience LLC. 
norepinephrine and serotonin levels to the normal range and systolic and diastolic blood pressures, retroperitoneal body fat, plasma insulin and glucose levels and HOMA-IR relative to vehicle-treated SHR controls. Such treatment also reduced plasma levels of C-reactive protein, leptin and norepinephrine and increased those of plasma adiponectin significantly relative to SHR controls. Finally, bromocriptine treatment significantly reduced hepatic levels of several proinflammatory pathway proteins and of the master transcriptional activators of lipogenesis, gluconeogenesis and free fatty acid oxidation versus control SHR rats (46). Cincotta and colleagues, who have pioneered this work, draw the analogy of the change in fat mass, insulin resistance in seasonal vertebrates to prepare them for their needs when famine or short supply of food occurs. The hepatic metabolism appears to be regulated by the clock pacemaker. Seasonally obese, insulinresistant animals evolved the ability to become hepatic insulin resistant to generate glucose when little to none is available in the wild and yet increase insulin-mediated hepatic lipogenesis to generate lipid as a fuel source for non-CNS tissue to thereby spare the produced hepatic glucose for the brain. Thus, it is suggested that metabolic syndrome and type 2 diabetes may be a maladaptation since humans fortunately in the modern world are less frequently exposed to food deprivation. Perhaps, timed bromocriptine may prevent them from developing metabolic syndrome and its associated morbidity. Fifty years later, there are still many questions that remain, but the journey continues to have interesting and potentially important therapeutic implications.

\section{Declaration of interest}

Dr Besser has no declarations of interest or funders and $\mathrm{Dr}$ Thorner is the founder and Chief Scientific Officer of Ammonett Pharma which is developing MK-0677 (ibutamoren) as ghrelin receptor agonist. None of the authors have any interests in the dopamine agonists at the time of this study.

Funding

This research did not receive any specific grant from any funding agency in the public, commercial or not-for-profit sector.

\section{References}

1 Fluckiger E \& Wagner HR. 2-Br-alpha-ergokryptin: influence on fertility and lactation in the rat. Experientia 196824 1130-1131. (https://doi.org/10.1007/BF02147804)

2 Shelesnyak MC. Progesterone reversal of ergotoxine induced suppression of early - pre-implantation - pregnancy. Acta Endocrinologica 195623 151-157.
3 Shelesnyak MC. Ergotoxine inhibition of deciduoma formation and its reversal by progesterone. American Journal of Physiology 1954179 301-304.

4 Lindner HR \& Shelesnyak MC. Effect of ergocornine on ovarian synthesis of progesterone and 20 alpha-hydroxy-pregn-4-en-3-one in the pseudopregnant rat. Acta Endocrinologica 196756 27-34.

5 Shelesnyak MC. Maintenance of gestation of ergotoxine-treated pregnant rats by exogenous prolactin. Acta Endocrinologica 195827 99-109.

6 Muller EE, Panerai AE, Cocchi D \& Mantegazza P. Endocrine profile of ergot alkaloids. Life Science 197721 1545-1558. (https://doi. org/10.1016/0024-3205(77)90231-4)

7 Frantz AG \& Kleinberg DL. Prolactin: evidence that it is separate from growth hormone in human blood. Science 1970170 745-747. (https://doi.org/10.1126/science.170.3959.745)

8 Kleinberg DL \& Frantz AG. Human prolactin: measurement in plasma by in vitro bioassay. Journal of Clinical Investigation 197150 1557-1568. (https://doi.org/10.1172/JCI106643)

9 Forsyth IA, Besser GM, Edwards CR, Francis L \& Myres RP. Plasma prolactin activity in inappropriate lactation. BMJ 19713 225-227. (https://doi.org/10.1136/bmj.3.5768.225)

10 Besser GM, Parke L, Edwards CR, Forsyth IA \& McNeilly AS. Galactorrhoea: successful treatment with reduction of plasma prolactin levels by brom-ergocryptine. BMJ 19723 669-672. (https:// doi.org/10.1136/bmj.3.5828.669)

11 Brun del Re R, Del Pozo E, De Grandi P, Friesen H, Hinselmann M \& Wyss $\mathrm{H}$. Prolactin inhibition and suppression of puerperal lactation by a Br-erocryptine (CB 154). A comparison with estrogen. Obstetrics and Gynecology $1973 \mathbf{4 1} 884-890$.

12 Del Pozo E, Del Re RB, Varga L \& Friesen H. The inhibition of prolactin secretion in man by CB-154 (2-Br-alpha-ergocryptine). Journal of Clinical Endocrinology and Metabolism 197235 768-771. (https://doi.org/10.1210/jcem-35-5-768)

13 MacLeod RM \& Lehmeyer JE. Studies on the mechanism of the dopamine-mediated inhibition of prolactin secretion. Endocrinology 197494 1077-1085. (https://doi.org/10.1210/endo94-4-1077)

14 Hwang P, Guyda H \& Friesen H. Purification of human prolactin. Journal of Biological Chemistry 1972247 1955-1958.

15 Corrodi H, Fuxe K, Hokfelt T, Lidbrink P \& Ungerstedt U. Effect of ergot drugs on central catecholamine neurons: evidence for a stimulation of central dopamine neurons. Journal of Pharmacy and Pharmacology 197325 409-412. (https://doi. org/10.1111/j.2042-7158.1973.tb10037.x)

16 Gibbs DM \& Neill JD. Dopamine levels in hypophysial stalk blood in the rat are sufficient to inhibit prolactin secretion in vivo. Endocrinology 1978102 1895-1900. (https://doi.org/10.1210/endo102-6-1895)

17 Thorner MO, McNeilly AS, Hagan C \& Besser GM. Long-term treatment of galactorrhoea and hypogonadism with bromocriptine. BMJ 19742 419-422. (https://doi.org/10.1136/bmj.2.5916.419)

18 Thorner MO, Martin WH, Rogol AD, Morris JL, Perryman RL, Conway BP, Howards SS, Wolfman MG \& MacLeod RM. Rapid regression of pituitary prolactinomas during bromocriptine treatment. Journal of Clinical Endocrinology and Metabolism 198051 438-445. (https://doi.org/10.1210/jcem-51-3-438)

19 Barrow DL, Tindall GT, Kovacs K, Thorner MO, Horvath E \& Hoffman JC Jr. Clinical and pathological effects of bromocriptine on prolactin-secreting and other pituitary tumors. Journal of Neurosurgery 198460 1-7. (https://doi.org/10.3171/jns.1984.60.1.0001)

20 Thorner MO, Perryman RL, Rogol AD, Conway BP, Macleod RM, Login IS \& Morris JL. Rapid changes of prolactinoma volume after withdrawal and reinstitution of bromocriptine. Journal of Clinical Endocrinology and Metabolism 198153 480-483. (https://doi. org/10.1210/jcem-53-3-480) 
21 Molitch ME. Diagnosis and treatment of pituitary adenomas: a review. JAMA 2017317 516-524. (https://doi.org/10.1001/ jama.2016.19699)

22 Liuzzi A, Chiodini PG, Botalla L, Cremascoli G \& Silvestrini F. Inhibitory effect of L-Dopa on GH release in acromegalic patients. Journal of Clinical Endocrinology and Metabolism 197235 941-943. (https://doi.org/10.1210/jcem-35-6-941)

23 Thorner MO, Chait A, Aitken M, Benker G, Bloom SR, Mortimer CH, Sanders P, Mason AS \& Besser GM. Bromocriptine treatment of acromegaly. BMJ 19751 299-303. (https://doi.org/10.1136/ bmj.1.5953.299)

24 Liuzzi A, Chiodini PG, Botalla L, Cremascoli G, Muller EE \& Silvestrini F. Decreased plasma growth hormone $(\mathrm{GH})$ levels in acromegalics following CB 154(2-Br-alpha ergocryptine) administration. Journal of Clinical Endocrinology and Metabolism 1974 38 910-912. (https://doi.org/10.1210/jcem-38-5-910)

25 Wass JA, Thorner MO, Morris DV, Rees LH, Mason AS, Jones AE \& Besser GM. Long-term treatment of acromegaly with bromocriptine. BMJ 19771 875-878. (https://doi.org/10.1136/bmj.1.6065.875)

26 Wass JA, Clemmons DR, Underwood LE, Barrow I, Besser GM \& Van Wyk JJ. Changes in circulating somatomedin-C levels in bromocriptine-treated acromegaly. Clinical Endocrinology 198217 369-377. (https://doi.org/10.1111/j.1365-2265.1982.tb01602.x)

27 Giustina A, Chanson P, Kleinberg D, Bronstein MD, Clemmons DR, Klibanski A, van der Lely AJ, Strasburger CJ, Lamberts SW, Ho KK et al. Expert consensus document: a consensus on the medical treatment of acromegaly. Nature Reviews Endocrinology 201410 243-248. (https://doi.org/10.1038/nrendo.2014.21)

28 Calne DB. Developments in the treatment of parkinsonism. New England Journal of Medicine 1976295 1433-1434. (https://doi. org/10.1056/NEJM197612162952511)

29 Cotzias GC, Van Woert MH \& Schiffer LM. Aromatic amino acids and modification of parkinsonism. New England Journal of Medicine 1967 276 374-379. (https://doi.org/10.1056/NEJM196702162760703)

30 Cotzias GC, Papavasiliou PS, Fehling C, Kaufman B \& Mena I. Similarities between neurologic effects of L-dopa and of apomorphine. New England Journal of Medicine 1970282 31-33. (https://doi.org/10.1056/NEJM197001012820107)

31 Vakil SD, Calne DB, Reid JL \& Seymour CA. Pyrimidyl-piperonylpiperazine (ET 495) in parkinsonism. In Advances in Neurology, pp 121-125. Ed DB Calne. New York: Raven Press, 1973.

32 Calne DB, Teychenne PF, Claveria LE, Eastman R, Greenacre JK \& Petrie A. Bromocriptine in Parkinsonism. BMJ 1974 4 442-444. (https://doi.org/10.1136/bmj.4.5942.442)

33 Teychenne PF, Leigh PN, Reid JL, Calne DB, Greenacre JK, Petrie A $\&$ Bamji AN. Idiopathic parkinsonism treated with bromocriptine.
Lancet 19752 473-476. (https://doi.org/10.1016/S01406736(75)90546-2)

34 Parkes JD, Marsden CD, Donaldson I, Galea-Debono A, Walters J, Kennedy G \& Asselman P. Bromocriptine treatment in Parkinson's disease. Journal of Neurology, Neurosurgery, and Psychiatry 197639 184-193. (https://doi.org/10.1136/jnnp.39.2.184)

35 Lieberman A, Kupersmith M, Estey E \& Goldstein M. Treatment of Parkinson's disease with bromocriptine. New England Journal of Medicine 1976295 1400-1404. (https://doi.org/10.1056/ NEJM197612162952504)

36 Kebabian JW \& Calne DB. Multiple receptors for dopamine. Nature 1979277 93-96. (https://doi.org/10.1038/277093a0)

37 Kebabian JW. Multiple dopamine receptors and their implications in medicine. Current Opinion in Neurology and Neurosurgery 19925 514-518.

38 Parkkinen L, O'Sullivan SS, Kuoppamaki M, Collins C, Kallis C, Holton JL, Williams DR, Revesz T \& Lees AJ. Does levodopa accelerate the pathologic process in Parkinson disease brain? Neurology 201177 1420-1426. (https://doi.org/10.1212/WNL.0b013e318232ab4c)

39 Kurlan R. 'Levodopa phobia': a new iatrogenic cause of disability in Parkinson disease. Neurology 200564 923-924.

40 Rinne UK, Krupp P, Lewitt PA \& Calne DB. Pleuropulmonary changes during long-term bromocriptine treatment for Parkinson's disease. Lancet 19811 44-45. (https://doi.org/10.1016/S0140-6736(81)90150-1)

41 McElvaney NG, Wilcox PG, Churg A \& Fleetham JA. Pleuropulmonary disease during bromocriptine treatment of Parkinson's disease. Archives of Internal Medicine 1988148 2231-2236. (https://doi.org/10.1001/archinte.1988.00380100089019)

42 Thorner MO, Flúckiger E \& Calne DB. Bromocriptine: A Clinical and Pharmacological Review. New York: Raven Press, 1980.

43 Defronzo RA. Bromocriptine: a sympatholytic, d2-dopamine agonist for the treatment of type 2 diabetes. Diabetes Care 201134 789-794. (https://doi.org/10.2337/dc11-0064)

44 Raskin PCA. Bromocriptine-QR therapy for the management of type 2 diabetes mellitus: developmental basis and therapeutic profile summary. Expert Review of Endocrinology and Metabolism 201611 $113-148$.

45 Gaziano JM, Cincotta AH, Vinik A, Blonde L, Bohannon N \& Scranton R. Effect of bromocriptine-QR (a quick-release formulation of bromocriptine mesylate) on major adverse cardiovascular events in type 2 diabetes subjects. Journal of the American Heart Association 20121 e002279.

46 Ezrokhi M, Luo S, Trubitsyna Y \& Cincotta AH. Neuroendocrine and metabolic components of dopamine agonist amelioration of metabolic syndrome in SHR rats. Diabetology and Metabolic Syndrome 20146 104. (https://doi.org/10.1186/1758-5996-6-104) 